\title{
An Association Between the Anemone, Cribrinopsis fernaldi, and Shrimps of the Families Hippolytidae and Pandalidae
}

\author{
Bradley G. Stevens and Paul J. Anderson \\ National Marine Fisheries Service, Alaska Fisheries Science Center, \\ Kodiak Laboratory, P.O. Box 1638, Kodiak, AK 99615, USA
}

\begin{abstract}
A previously undocumented association between the pink sea anemone Cribrinopsis fernaldi and several species of Caridean shrimp was observed from a submersible in Kodiak, Alaska. Shrimp were aggregated in a radial pattern around anemones, beneath or just beyond the tentacle canopy. Species collected with a suction sampler included Eualus suckleyi, Spirontocaris sp., Lebbeus grandimanus, L. groenlandicus and Pandalus tridens, but not Pandalus borealis, although it was probably also present. Numbers of shrimp per anemone increased with depth from 61 to $115 \mathrm{~m}$, and more shrimp were observed on silty-sand than on sandy-gravel substrates. While associations between actinians and Hippolytid shrimp are common in tropical waters, this association is unique because of its northern geographic location and the involvement of Pandalid shrimp.
\end{abstract}

Key words: Alaska, anemones, shrimp, symbiosis

\section{Introduction}

Many species of decapod crustaceans exhibit commensal associations with other organisms (Ross, 1983). Perhaps the best known associations are those between Caridean shrimps (of the families Palaemonidae and Hippolytidae) and sea anemones. Bruce (1976) and Ross (1983) provide extensive reviews of these and other crustacean symbioses. The majority of observations of commensalism involving shrimps and actinians have occurred in tropical waters of the Western Caribbean or Indo-Pacific, although Suzuki and Hayashi (1977) reported on similar associations in Japanese waters. Only one decapod-anemone association has been reported from the eastern North Pacific ocean. The Hippolytid Lebbeus grandimanus has been reported to occur in association with the pink anemone Cribrinopsis fernaldi, and is occasionally also found on anemones of the genus Urticina (Tealia) (Butler, 1980; for an excellent photograph see Barr and Barr, 1983). In this report we document association between $C$. fernaldi and several additional species of the families Hippolytidae and Pandalidae, in Alaskan waters.

\section{Materials and Methods}

Initial observations of shrimp aggregations were made in Chiniak Bay, Kodiak Island, Alaska $\left(57^{\circ} 43^{\prime} \mathrm{N}\right.$, $152^{\circ} 20^{\prime} \mathrm{W}$ ) from the 2-person submersible Delta (Delta Oceanographic, Torrance, CA, USA) during 18-30
April 1991. At that time, we first observed and photographed aggregations of numerous shrimp around the bases of the pink anemone, Cribrinopsis fernaldi. On 8 and 12 April, 1992, we counted shrimp associated with pink anemones during dives 1 and 4 on a sandy-gravel slope in Chiniak Bay (Site 1). Starting at $120 \mathrm{~m}$ depth, the sub traveled upslope and stopped whenever an anemone came within view of the observer, who counted all shrimp visibly associated with the anemone, and recorded the depth of the observation.

Shrimp associated with pink anemones were collected on 11 May 1992 using a venturi-driven suction sampler mounted on the Delta. Collections were made during dive 2 at Site $1(60-120 \mathrm{~m}$, mean $112 \mathrm{~m}$ ), and dive 3 at site 2 , a silty-sand substrate ranging from 103 to $137 \mathrm{~m}$ depth (mean $119 \mathrm{~m}$ ). To avoid startling the shrimp, the $5-\mathrm{cm}$ diameter hose was held above the anemone prior to starting the pump, and then pressed down over the anemone and nearby sediments until the anemone completely contracted. Anemones which were already contracted, did not have shrimp associated with them and were not sampled. In this manner, ten anemones were sampled during dive 2 (site 1), and eight during dive 3 (site 2). All shrimp were collected in one or two fine mesh plankton nets connected to the suction sampler. Many shrimp escaped during capture, particularly the larger ones (presumably including 
Pandalus borealis), so data in Table 1 represent only the species assemblage of capturable specimens, and are not quantitative. We could not keep samples from individual anemones separate without returning to the surface repeatedly, consequently, we could calculate the mean number of shrimps captured per anemone, but not the standard deviation. On the surface, shrimp were fixed in $10 \%$ buffered formalin for return to the lab, where they were identified, counted, and stored in $70 \%$ ethanol. Carapace length (CL) of each shrimp was measured to the nearest $0.05 \mathrm{~mm}$ from the right eye socket to the rear margin of the carapace, using digital calipers. Lengths were compared using oneway anova (SPSS procedure Oneway), and $F$ values $<0.05$ were considered significant.

\section{Results}

Shrimp were observed to be aggregated and radially oriented around individual pink anemones $(C$. fernaldi). Over 100 shrimp are present in Fig. 1, although this may be an exceptional example. Although solitary shrimp were occasionally observed in association with the giant anemone (Metridium giganteum), they were never aggregated around it. The majority of aggregated shrimp were observed in contact with the sediment immediately beneath or close to the extended tentacles of $C$. fernaldi and arranged in a radial pattern around the anemone, with heads pointing outward. Based on visual observations, distance of shrimp from the anemone seemed to be correlated with shrimp size, as larger shrimp were farther away, and smaller ones closer to the anemone base. Shrimp tended to be more numerous on the downcurrent side of anemones, and were occasionally observed on their side, with the dorsal surface facing into the current. Shrimp were also observed with their telsons up against the stalk of the anemone, in an almost vertical position. Some specimens of $L$. grandimanus were observed walking on the tentacles and oral surface of $C$. fernaldi, and a few were observed on the oral surface of $M$. giganteum as well. We also commonly observed shrimp aggregating in depressions of the seafloor sediment and around other objects such as drift kelp, but the orientation of shrimp in these aggregations appeared to be random, and not radial. Shrimp did not aggregate around anemones whose tentacles were retracted.

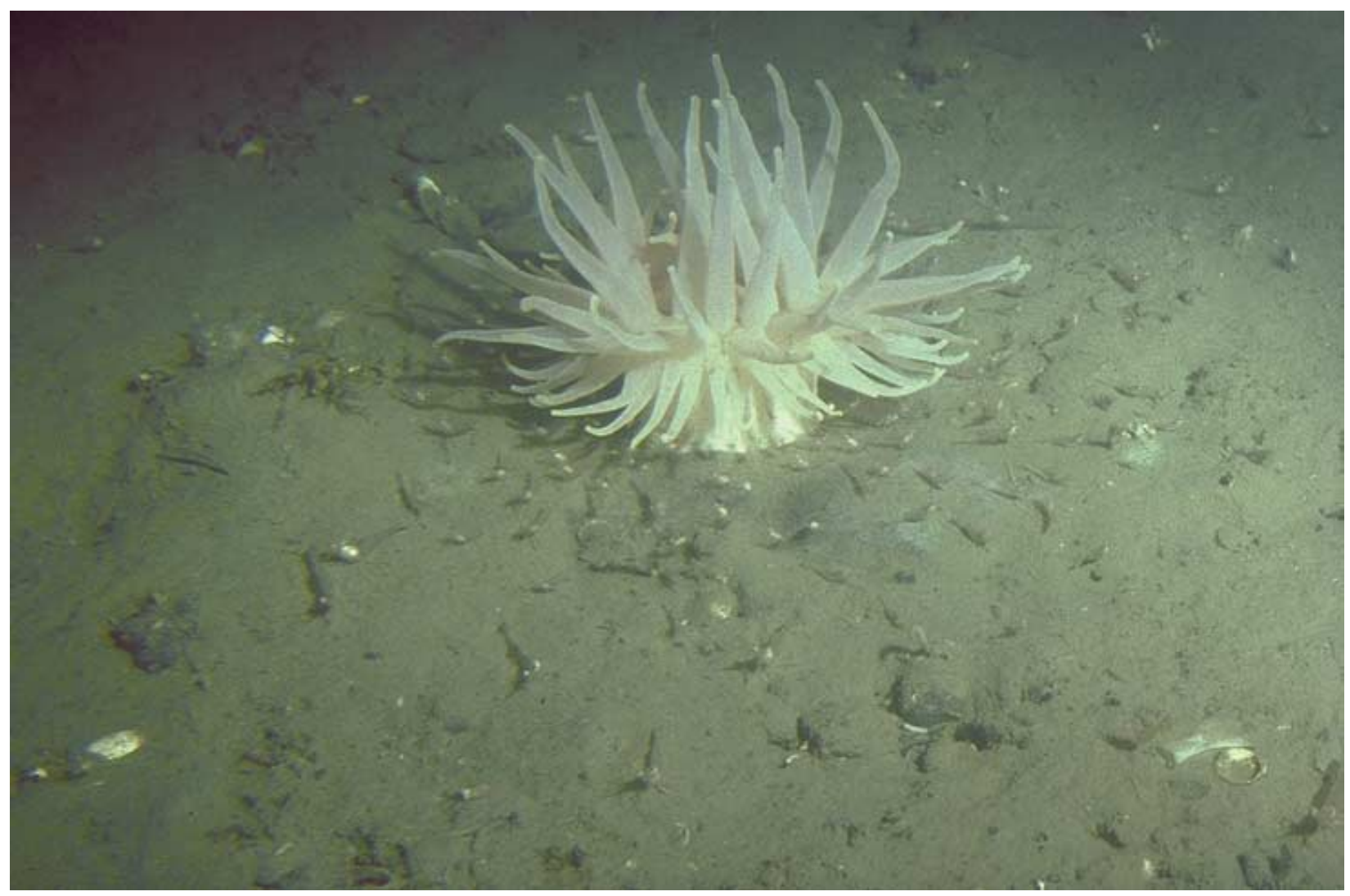

Fig. 1. Hippolytid and Pandalid shrimps aggregated around the pink anemone Cribrinopsis fernaldi, at a depth of $119 \mathrm{~m}$ in Kodiak, Alaska, USA. Approximately 100 shrimp are present. Note the radial distribution pattern, with heads pointing outwards and tails in, and that larger shrimp appear to be farther from the anemone. Photograph by Brad Stevens. 
Shrimp taxa which were collected from aggregations associated with pink anemones (Table 1) included four Hippolytids (Eualus suckleyi, Spirontocaris sp., Lebbeus grandimanus, L. groenlandicus) and one Pandalid (Pandalus tridens). The most abundant species in the samples was E. suckleyi. Shrimp appeared to be indifferent to the presence of the submersible and its lights, only moving away when approached to within several centimetres. However, shrimp were easily alarmed by vibrations from the suction pump motor and hose tip, and many of the larger shrimp (possibly $P$. tridens, $P$. goniurus, or $P$. borealis, all of which are known to inhabit the sampling area), were able to escape, so these samples do not reflect their presence or abundance.

Shrimp number and type varied with depth and substrate. The shrimp/anemone ratio was higher in samples collected from silty-sand (Site $2,=8.75$; Table 1) than from sandy/gravel substrates (Site $1,=4.0$ ), but the number of aggregated species was greater at Site 1 ( 5 vs. 3). Shrimp density observed from the submersible (including shrimp not associated with anemones) also appeared to be greater on silty-sand than on sandy-gravel substrates, but this was not estimated quantitatively. There was no significant difference in mean CL of Eualus suckleyi $\left(F_{17,49}=\right.$ $0.293, P=0.59, n=66)$ or Spirontocaris sp. $\left(F_{6,19}=\right.$ 1.198, $P=0.28, n=25$ ) (Table 1) between the two collection sites. On the sandy-gravel substrate at Site 1 , the mean number of shrimp seen in association with pink anemones (shrimp/anemone) increased with depth from 0.25 at $61 \mathrm{~m}$, to 6.6 at $116 \mathrm{~m}$ (Table 2), probably reflecting a general increase in shrimp density with depth. Water temperatures ranged from $5.3^{\circ} \mathrm{C}$ to $5.0^{\circ} \mathrm{C}$ over the same depth range.

\section{Discussion}

Both the pink anemone, Cribrinopsis fernaldi, and the giant anemone, Metridium giganteum, are abundant in Chiniak Bay, often occurring adjacent to each other. Yet shrimp were observed aggregating only around the pink anemone, indicating that shrimp can distinguish between these two species. Structurally, the two species of anemone are quite different. The stalk of C. fernaldi is short and thick, $5-10 \mathrm{~cm}$ in height and width, and is crowned by $60-80$ thick tentacles of 5-10 $\mathrm{cm}$ length, which extend outward, forming a canopy under which many shrimp were situated. It usually occurs as solitary individuals anchored to rocks or shells in sandy sediments. In contrast, M. giganteum usually has a much longer stalk (up to $50 \mathrm{~cm}$ ) crowned by a thin, feathery, highly branched mass of $>200$ minute tentacles, and occurs on both sandy and rocky substrates, often in clusters.

Most observations of symbiotic associations between decapods and actinians have occurred in tropical waters. Stanton (1977) reported that several species of shrimp, including Periclimenes pedersoni, P. yucatanicus, and P. rathbunae (all Palaemonids), Thor amboinensis (a Hippolytid), and crabs, including Mithrax sp. and Stenorhynchus seticornis (both Majids), cohabited with the anemone Lebrunia danae on Jamaican coral reefs. Many of the species which cohabit with $L$. danae also cohabit with the anemone Bartholomea annulata, as do the snapping shrimps Alpheus armatus (Herrnkind et al., 1976), and A. immaculatus (Knowlton and Keller, 1983). P. yucatanicus have also been reported to cohabit with Condylactis gigantea (Limbaugh et al., 1961) and rarely with Rhodactis sanctithomae (Williams and

TABLE 1. Numbers and lengths of shrimp species collected by submersible from aggregations surrounding the pink anemone Cribrinopsis fernaldi, at two different sites. Mean \pm sd given for Eualus sp. and Spirontocaris sp., actual measurements for all others. One specimen of L. grandimanus was not measured. CL = carapace length. Depths are average depth at each site.

\begin{tabular}{|c|c|c|c|}
\hline Species & $\begin{array}{c}\text { Site } 1 \\
112 \mathrm{~m} \\
\text { sandy-gravel }\end{array}$ & $\begin{array}{c}\text { Site } 2 \\
119 \mathrm{~m} \\
\text { silty-sand }\end{array}$ & $\begin{array}{l}\qquad \mathrm{CL}(\mathrm{mm}) \\
\text { Actual or Mean } \pm \mathrm{sd} \text {, }\end{array}$ \\
\hline Anemones sampled & 10 & 8 & \\
\hline Eualus suckleyi & 17 & 49 & $6.6 \pm 1.3$ \\
\hline Spirontocaris sp. & 6 & 19 & $5.1 \pm 0.9$ \\
\hline Pandalus tridens & 3 & 0 & $7.4,13.3,15.5$ \\
\hline Lebbeus groenlandicus & 2 & 0 & $6.2,8.3$ \\
\hline Lebbeus grandimanus & 2 & 1 & $6.0,6.8$ \\
\hline Mean \# shrimp/anemone & 4.0 & 8.75 & \\
\hline
\end{tabular}


TABLE 2. Numbers of shrimp counted per anemone, by depth, during dives 1 and 4 on a sandy-gravel slope (Site 1) in Chiniak Bay, Kodiak AK, USA. Dives ascended from $120 \mathrm{~m}$ to $60 \mathrm{~m}$ depth. $\mathrm{sd}=$ standard deviation.

\begin{tabular}{|c|c|c|c|c|c|c|c|c|c|c|c|}
\hline \multirow{2}{*}{$\frac{\text { Date }}{5 / 8 / 92}$} & \multirow{2}{*}{$\frac{\text { Dive }}{1}$} & \multicolumn{2}{|l|}{ Depth } & \multicolumn{6}{|c|}{ Counts } & \multirow{2}{*}{$\begin{array}{c}\text { Mean } \\
0.25\end{array}$} & \multirow{2}{*}{$\begin{array}{l}\mathrm{sd} \\
0.5\end{array}$} \\
\hline & & 61 & 0 & 0 & 0 & 1 & & & & & \\
\hline $5 / 8 / 92$ & 1 & 76.2 & 0 & 1 & & & & & & 0.50 & 0.7 \\
\hline $5 / 12 / 92$ & 4 & 91.4 & 4 & 3 & 2 & 6 & & & & 3.75 & 1.7 \\
\hline $5 / 12 / 92$ & 4 & 94.5 & 2 & 0 & 1 & 3 & & & & 1.50 & 1.3 \\
\hline $5 / 12 / 92$ & 4 & 97.5 & 5 & & & & & & & 5.00 & \\
\hline 5/8/92 & 1 & 100.6 & 9 & 3 & 2 & 3 & 0 & 4 & & 3.50 & 3.0 \\
\hline $5 / 12 / 92$ & 4 & 105.2 & 3 & 3 & 5 & 0 & 4 & 5 & & 3.33 & 1.9 \\
\hline 5/8/92 & 1 & 115.2 & 3 & 9 & 5 & 9 & & & & 6.50 & 3.0 \\
\hline $5 / 8 / 92$ & 1 & 115.8 & 6 & 5 & 7 & 6 & 8 & 8 & 6 & 6.57 & 1.1 \\
\hline
\end{tabular}

Williams, 1982). The shrimp Lysmata grabhami has been reported in association with the anemone Stoichactis helianthis at Antigua (Chace, 1972) and with an unspecified anemone in the Indian Ocean (Bruce, 1974). Manning (1970) described a new species of Majid crab, Mithrax commensalis, which was found only in association with anemones of the genus Stoichactis, from Dominica in the eastern Caribbean.

Suzuki and Hayashi (1977) reported on associations between palaemonid and hippolytid shrimps and sea anemones in the subtropical waters of Suruga Bay, Japan. One hippolytid (Thor amboinensis) and four palaemonid shrimps (Hamopontonia corallicola, Periclimenes brevicarpalis, $P$. ornatus, and $P$. holthuisi) were observed associating with several species of anemones including Parasicyonis actinostroides, P. maxima, Radianthus maculata, and Dofleinia armata. Observations of $D$. armata occurred to $40 \mathrm{~m}$, and all others were less than $20 \mathrm{~m}$ deep. The most common symbiont was $P$. ornatus, comprising $76 \%$ of observed shrimp. No species-specific associations were observed; each species of shrimp occurred with multiple species of anemones and vice versa. For most of these shrimp species, only 1 or 2 individuals, including male-female pairs, occurred on each anemone, although up to 50 T. amboinensis occurred on a single host. Shrimp occurred most often on or between the tentacles, or on the oral disk, rather than beneath the tentacle canopy. $H$. corallicola, P. brevicarpalis, and P. ornatus were all observed to consume parts of their host anemones. In many respects, these observations are similar to those of tropical "cleaner" shrimps, in terms of behavior, low numbers per anemone, and position on the host.

Observations of shrimp-anemone associations in temperate or boreal waters, or involving Pandalid shrimp, are sparse and anecdotal. Howard (1982) reported that $P$. borealis formed clusters of up to 20 shrimp around the base of the deeplet, Bolocera tuediae, remarkably similar to our observations. Other associations similar to the one we describe have been observed in the Northwest Atlantic between unidentifed shrimp species and Bolocera tuediae, Cerianthus borealis, and Actinoscyphia saginata (P. Auster, Univ. of Connecticut, Groton CI, USA, pers. comm., October 1993). Shepard et al. (1986) observed Pandalids adjacent to tubes of Cerianthus sp. Moffitt and Parrish (1992) made submersible observations of the Pandalids Heterocarpus laevigatus and $H$. ensifer in Hawaiian waters, and reported that the latter species often concentrated around high relief features over otherwise flat, sandy, substrates, but such features included rocks as well as anemones, and no host specificity was indicated. Bukin and Zgurovsky (1998) indicated a close association between Pandalus hypsinotus and anemones and crinoids in the northwestern Sea of Japan, but the details are obscure.

Many of the tropical shrimp species reported in association with anemones are "cleaner" shrimps (particularly $P$. pedersoni, $P$. yucatanicus, and $L$. grabhami), belonging to the families Palaemonidae and Hippolytidae. Stanton (1977) noted that most of the shrimps he observed occupied the "over" or "onfrond" micro-habitat, as opposed to being "underfrond". For these shrimp, there is an obvious 
advantage in occupying highly visible habitats where they can be noticed by fish in need of cleaning. While most of the species we observed in association with pink anemones were also Hippolytids, most occupied understory habitats, and none have been reported exhibiting cleaning activity, including Lebbeus spp., which commonly occupy the "on-frond" habitat.

A common feature of shrimp-anemone associations is the anatomy of the host anemones, which usually have large, fleshy tentacles, as opposed to the fine, feathery tentacles of $M$. giganteum. Stanton (1977) reported a significant correlation between anemone frond area and the number of associated decapod species. The presence of actinians on crab carapaces may help protect their decapod hosts from predation (Ross, 1983). Shrimp occupying the "underfrond" habitat probably derive some protection from demersal feeding predators, such as Pacific cod (Gadus macrocephalus) in the Northeast Pacific. This hypothesis is supported by the observation that shrimp did not aggregate around contracted anemones. Thus, anemones which have short stalks and fleshy tentacles close to the substrate, such as $C$. fernaldi, may provide better shelter, and harbor more individuals, than anemones like $M$. giganteum which have finer tentacles further from the substrate. Fleshy tentacles may bear larger or more numerous cnidocytes, and are more substantial as well, so can easily support shrimp walking about on them, whereas the fine tentacles of $M$. giganteum may provide less support for symbionts. Whether $C$. fernaldi derives any benefit from its association with shrimp is unknown, although Smith (1977) demonstrated that $A$. armatus was capable of protecting its host (B. annulata) from attacks by predatory polychaetes which partially consumed and killed the anemones in the absence of shrimp.

We were unable to collect the largest shrimps observed, which may have been Pandalus tridens, $P$. goniurus, or $P$. borealis. On the other hand, the few $P$. tridens we did capture may have been "just passing by" rather than actively associating with the anemone when they were collected. Further detailed observations are warranted to clarify this relationship, and to determine whether other species of Pandalus were indeed present. Butler (1980) reported the apparent preference of $P$. tridens for rocky substrates, which may explain the absence of this species from samples taken in the featureless silty-sand environment of outer Chiniak Bay (Table 1). In such environments, there is less potential cover for shrimp, which may explain the greater number of shrimp collected from anemones there. In contrast, sandygravel habitat was more fractal, with broken, rocky structure providing more potential cover.

Our observations indicate that shrimp of the genera Eualus, Lebbeus, Pandalus, and Spirontocaris are facultative symbionts with the pink anemome C. fernaldi. Whether this relationship is commensal or mutual, and whether shrimp would aggregate around similarly shaped inanimate objects, remains to be determined. All of these shrimp species, as well as the pink anemome, are apparently able to survive and prosper independently. Shrimp of these genera are frequently encountered among commercial catches of Pandalid shrimp in both the Northeast Pacific and the Northwest Atlantic oceans (Butler, 1980). Our observations indicate that individuals of these genera may occur in very close proximity, and that anemonecentered aggregations may contribute substantially to patchiness of shrimp distribution.

\section{Acknowledgements}

We gratefully thank Dr. R. Slater and the crew of the DSRV Delta for their helpful assistance with this project. Jan Haaga assisted with shrimp counts. This research was supported in part by the West Coast National Undersea Research Center, University of Alaska, Fairbanks, AK.

\section{References}

BARR, L., and N. BARR. 1983. Under Alaskan Seas. Alaska Northwest Publishing, Anchorage, AK, 208 p.

BRUCE, A. J. 1974. On Lysmata grabhami (Gordon), a widely distributed tropical Hippolytid shrimp (Decapoda, Caridea). Crustaceana, 27(1): 107-109.

BRUCE, A. J. 1976. Shrimps and prawns of coral reefs, with special reference to commensalism. In: Biology and Geology of Coral Reefs (O. A. Jones and R. M Dean, eds.), Vol. 3, p. 37-94. Academic Press, NY.

BUKIN, S. D., and K. A. ZGUROVSKY. 1998. Distribution patterns, biology and behavior of humpback shrimp (Pandalus hypsinotus) in the northwestern sea of Japan. Morskie promyslovye bespozvonochnye. VNIRO, Moscow, p 108-119.

BUTLER, T. H. 1980. Shrimps of the Pacific Coast of Canada. Can. Bull. Fish. Aquat. Sci., 202, 202 p.

CHACE, F. A., Jr. 1972. the shrimps of the SmithsonianBredin Caribbean Expeditions with a summary of the West Indian shallow water species (Crustacea: Decapoda: Natantia). Smithsonian Contrib. Zool., 98: 1-179.

HERRNKIND, W., G. STANTON, and E. CONKLIN. 1976. Initial characterization of the commensal complex 
associated with the anemone, Lebrunia danae, at Grand Bahama. Bull. Mar. Sci., 26(1): 65-71.

HOWARD, F. G. 1982. Of shrimps and sea anemones; of prawns and other things. Scott. Fish. Bull., 47: 39-40.

KNOWLTON, N., and B. D. KELLER. 1983. A new, sibling species of snapping shrimp associated with the Caribbean sea anemone Bartholomea annulata. Bull. Mar. Sci., 33(2): 353-362.

LIMBAUGH, C., H. PEDERSON, and F. A. CHACE, Jr. 1961. Shrimps that clean fishes. Bull. Mar. Sci. Gulf and Carib., 11(2): 237-257.

MANNING, R. 1970. Mithrax (Mithraculus) commensalis, a new West Indian spider crab (Decapoda, Majidae) commensal with a sea anemone. Crustaceana, 19(2): 157-160.

MOFFITT, R. B., and F. A. PARRISH. 1992. An assessment of the exploitable biomass of Heterocarpus laevigatus in the main Hawaiian Islands. Part 2: Observations from a submersible. Fish. Bull., 90: 476-482.

ROSS, D. M. 1983. Symbiotic Relations. In: The Biology of
Crustacea (D. Bliss, ed.), Vol. 7., p 163-211. Academic Press, NY.

SHEPARD, A. N., R. B. THEROUX, R. A. COOPER, and J. R. UZMANN. 1986. Ecology of Ceriantharia (Coelenterata, Anthozoa) of the Northwest Atlantic from Cape Hatteras to Nova Scotia. Fish. Bull. U.S., 84(3): 625-646.

SMITH, W. L. 1977. Beneficial behavior of a symbiotic shrimp to its host anemone. Bull. Mar. Sci., 27(2): 343-346.

STANTON, G. 1977. Habitat partitioning among associated decapods with Lebrunia danae at Grand Bahama. Proc. Third Int. Coral Reef Symp., Miami, Florida, May 1977. p. 169-175.

SUZUKI, K., and K.-I. HAYASHI. 1977. Five caridean shrimps associated with sea anemones in central Japan. Publ. Seto Mar. Biol. Lab., 24(1/3): 193-208.

WILLIAMS, E. H., Jr., and L. B. WILLIAMS. 1982. First report of Periclimenes yucatanensis (Ives)(Decapoda, Palaemonidae) in association with a Corallimorpharian anemone. Crustaceana, 42(3): 318-319. 